MŁODY JURYSTA 2018/4 - numer specjalny - I Konferencja Młodych Naukowców Prawa Administracyjnego

\title{
Sebastian Czechowicz
}

\section{Sprzeciw od decyzji kasatoryjnej jako novum w postępowaniu przed Wojewódzkimi Sądami Administracyjnymi}

\begin{abstract}
Decyzja kasatoryjna jest instytucją procedury administracyjnej o charakterze kontrolnym. Obszarowo scharakteryzowana w artykule 138 ustawy - Kodeks postępowania administracyjnego. W momencie jej zastosowania przez organ odwoławczy sprawa może być przekazana do ponownego rozpoznania. By uniknąć sytuacji nadmiernego stosowania tej instytucji, nowelizacją z 1.6.2017 r. wprowadzono sprzeciw od wydanej decyzji kasacyjnej, którą strona ma prawo wnieść do wojewódzkiego sądu administracyjnego. Przedmiotowy artykuł koncentruje się na ocenie przedstawionej tematyki, w odniesieniu do uprawnień procesowych strony postępowania.
\end{abstract}

\section{Decyzja kasatoryjna jako instytucja w postępowaniu administracyjnym}

Instytucja decyzji kasatoryjnej określona w artykule $138 \S 1-2 \mathrm{~b} \mathrm{KPA}^{1}$ jest szczególną formą kontroli decyzji administracyjnych, zapadłych w niższej instancji. Stosować ją może organ odwoławczy, gdy stwierdzi błędy w ustaleniu okoliczności faktycznych w postępowaniu przed organem I instancji. Doktryna wyróżnia dwie postaci decyzji kasacyjnej: formę typową i związaną z przekazaniem sprawy do ponownego rozpatrzenia. Pierwsza z nich odnosi się do istnienia przesłanki braku podstaw do rozpatrzenia konkretnej sprawy na gruncie postępowania administracyjnego. Znacznie więcej uwagi zwrócić należy na drugą, w przypadku której sprawa wówczas kierowana jest do ponownego rozpoznania, a samo postępowanie toczy się praktycznie od początku. Warunkiem sine qua non zastosowania tejże instytucji jest przesłanka dotycząca naruszenia przepisów prawa, które miały istotny wpływ na treść rozstrzygnięcia ${ }^{2}$. Charakter tego sformułowania jest ocenny i kształtuje się na gruncie konkretnego przypadku. Organ odwoławczy, przekazując decyzję do ponownego rozpoznania,

\footnotetext{
${ }^{1}$ Ustawa z 14.6.1960 r. Kodeks postępowania administracyjnego, tekst jedn. Dz. U. z 2017 r., poz. 1257, dalej jako KPA.

${ }^{2}$ B. Adamiak, Prawo procesowe administracyjne, [w:] System Prawa Administracyjnego, red. R. Hauser, Z. Niewiadomski, A. Wróbel, Warszawa 2014, s. 246-247.
} 
MŁODY JURYSTA 2018/4 - numer specjalny - I Konferencja Młodych Naukowców Prawa Administracyjnego

winien zakreślić okoliczności istotne dla sprawy, które organ I instancji zobligowany jest wziąć pod uwagę przy ponownym rozpoznaniu sprawy.

Klasyfikacja prawna tej instytucji wydaje się być niespójna. Poglądy orzecznictwa kłócą się z doktryną w kwestii charakteru decyzji kasatoryjnej. Stanowisko Naczelnego Sądu Administracyjnego ${ }^{3}$ z 1991 r. kształtuje decyzję kasatoryjną, jako nie będącą decyzją ostateczną w myśl przepisów wspomnianej ustawy. Co więcej, na tej podstawie nie daje ona możliwości do wznowienia postępowania administracyjnego ${ }^{4}$. Glosą do tegoż wyroku J. Zimmermann krytycznie odniósł się do stanowiska orzecznictwa powołując się na artykuł $16 \S 1 \mathrm{KPA}$. Autor uznał, że „nie ma zatem żadnej wątpliwości, że decyzja kasacyjna, skoro jest wydana przez organ drugiej instancji, staje się decyzją ostateczną"5. W świetle nowelizacji ustawy Prawo o postępowaniu przed sądami administracyjnymi ${ }^{6}$ twierdzenie to traci na słuszności, gdyż wprowadzony Rozdział 3a determinuje instytucję sprzeciwu od decyzji kasacyjnej. W artykule 64a niniejszej ustawy stwierdzono bowiem, że „od decyzji, o której mowa $\mathrm{W}$ art. $138 \S 2$ (...) skarga nie przysługuje, jednakże strona niezadowolona $\mathrm{z}$ treści decyzji może wnieść od niej sprzeciw (...)"ᄁ7. Norma ta dopuszcza zatem szczególną drogę zaskarżenia postanowienia organu, który zdecydował o ponownym rozpatrzeniu sprawy w I instancji, tak, aby ukierunkować postępowanie administracyjne na rozstrzygnięcie wątpliwości w danej mierze przez organ II instancji lub sąd administracyjny, a nie przedłużać postępowanie poprzez nałożenie na organ niższej instancji obowiązku ponownego rozpoznania sprawy. Przytoczone stanowisko NSA z 22.5.1991 r. jest zatem jak najbardziej aktualne, co do ostateczności tejże, przy uwzględnieniu najnowszej nowelizacji. Linia orzecznicza $w$ tym zakresie została podtrzymana przez Wojewódzki Sąd Administracyjny ${ }^{8}$ we Wrocławiu, który stwierdził, że „decyzja kasatoryjna nie wyczerpuje toku postępowania administracyjnego (art. $138 \S 2$ k.p.a.), a więc nie staje się decyzją ostateczną dającą podstawę do wznowienia postępowania w sprawie (art. 145 § 1 k.p.a.)"9. Jednakże przy uwzględnieniu ewentualnego oddalenia sprzeciwu decyzja kasacyjna pozostaje ostateczna, co jednoznacznie potwierdza tezę

\footnotetext{
${ }^{3}$ Dalej także jako NSA.

${ }^{4}$ Wyrok NSA z 22.5.1991 r., sygn. akt IV SA 349/91, OSP 1991, z.10, poz. 229.

${ }^{5}$ J. Zimmermann, Glosa do wyroku NSA z 22.5.1991 r., OSP 1991, z. 10, poz.229. [w:] G. Łaszczyca, Cz.

Martysz, A. Matan, Kodeks postepowania administracyjnego: Komentarz. Tom I do art. 1 - 103, Warszawa 2010, s. $271-272$.

${ }^{6}$ Ustawa z 30.8.2002 r. Prawo o postępowaniu przed sądami administracyjnymi, tekst jedn. Dz.U. z 2017 r., poz. 1369, dalej jako PPSA.

${ }^{7}$ J. Zimmermann, op.cit., s. $271-272$.

${ }^{8}$ Dalej także jako WSA.

${ }^{9}$ Wyrok WSA we Wrocławiu z 9.3.2017 r., sygn. akt IV SA/Wr 569/16, LEX nr 2273231.
} 
MŁODY JURYSTA 2018/4 - numer specjalny - I Konferencja Młodych Naukowców Prawa Administracyjnego

zaprezentowaną na początku, że natura decyzji kasatoryjnej jest niejednorodna i kształtuje się na kanwie konkretnej sprawy.

Ten szczególny charakter instytucji związanej zarówno z wydaniem decyzji kasatoryjnej, jak i możliwością wniesienia odeń sprzeciwu, skłania ku twierdzeniu Naczelnego Sądu Administracyjnego, że orzeczenie to nie ma przymiotu ostateczności. Warto jednak mieć na uwadze słuszne stanowisko, że „decyzja kasacyjna jest decyzją czysto procesową $<<$ międzyinstancyjną>>, nie załatwia sprawy co do istoty. Budziłoby zastrzeżenie dopuszczenie wkroczenia sądu administracyjnego swoim orzeczeniem w tok postępowania administracyjnego merytorycznego, toczącego się przed organem pierwszej instancji i zmierzającego do załatwienia sprawy, do czego w żadnej mierze sąd administracyjny nie jest uprawniony"10.

Warto również podzielić pogląd o pewnej zależności zachodzącej pomiędzy ostatecznością a prawomocnością decyzji administracyjnej. Otóż, nie każda z decyzji będących ostatecznymi w myśl przepisów ustawy będzie cechowała się prawomocnością. Jednakże decyzja prawomocna ex lege jest ostateczna ${ }^{11}$.

\section{Decyzja kasatoryjna a przedłużenie postępowania administracyjnego}

Wydanie przez organ II instancji decyzji kasacyjnej wiąże się dla strony z brakiem stabilizacji sytuacji w obrocie prawnym, a dotyczącej toczącego się postępowania administracyjnego. Organ, od orzeczenia którego wniesiono środek odwoławczy skutkujący wydaniem przedmiotowej decyzji, jest zobowiązany do ponownego zajęcia się sprawą. Implikacją tychże jest zachwianie pewności wspomnianej sytuacji prawnej nie tylko stron, ale także obrotu prawnego dotykającego pośrednio bądź bezpośrednio stan prawny wspomnianych podmiotów postępowania. Decyzja kasatoryjna wprowadza konieczność ponownego zbadania stanu faktycznego i wydania określonego orzeczenia w sprawie. Ma to znakomity wpływ na zjawisko przewlekłości postępowania, spowodowane nie opieszałością organu, lecz koniecznością ponownego zbadania stanu faktycznego sprawy.

Postępowanie administracyjne ma swoistą specyfikę, która odróżnia je od innych procedur. Przeważnie ukształtowane jest na płaszczyźnie organ - obywatel, a wektorem

\footnotetext{
${ }^{10}$ A. Łopatka (red), Państwo prawa, administracja, sadownictwo: prace dedykowane prof. dr. hab. Januszowi Łętowskiemu w 60. rocznice urodzin, Scholar 1999, s. 335.

${ }^{11}$ Podobnie: A. Rychter, Res iudicata $w$ postępowaniu administracyjnym, LEX, 2014.
} 
MŁODY JURYSTA 2018/4 - numer specjalny - I Konferencja Młodych Naukowców Prawa Administracyjnego

jest załatwienie sprawy na gruncie materialnych ustaw szczególnych. Organ rozpatrujący odwołania od decyzji organów I instancji zobligowany jest do wskazania ewentualnych uchybień proceduralnych, czy naruszenia zasad i norm prawa materialnego. Rodzi się wówczas pytanie dotyczące ukształtowania procedury w ten sposób, by organ II instancji mając realną możliwość zmiany decyzji, zmieniał ją w zakresie, w jakim została ona wadliwie sformułowana, nie wykorzystując instytucji decyzji kasatoryjnej w większości przypadków. Niefortunnie częściej wykorzystywany jest drugi wariant ${ }^{12}$.

W tym miejscu należy zaznaczyć, że do skrócenia przebiegu całego postępowania administracyjnego kluczową rolę odgrywa organ odwoławczy, który rozpatrując odwołanie może skorzystać z kompetencji przewidzianych w artykule $138 \S 1$ KPA. Może on bowiem orzec co do istoty sprawy, uchylając część bądź całość decyzji organu I instancji, bez konieczności jego powtórnego angażowania na podstawie art. $138 \S 2$ KPA. Decydujący wpływ na korzystanie $\mathrm{z}$ narzędzi przewidzianych $\mathrm{w}$ art. $138 \S 2$ KPA ma fakt wprowadzenia przesłanki ,istotnego wpływu na treść rozstrzygnięcia”. To ocenne sformułowanie doprowadza do wydawania decyzji kasatoryjnych, które w niektórych przypadkach mogły zamienić orzeczenia organu II instancji, co do istoty sprawy. Ustawodawca umożliwił stronie przeciwdziałanie takiemu postanowieniu organu nadrzędnego. Sprzeciwem od decyzji kasatoryjnej strona może domagać się jej uchylenia w trybie sądowej kontroli nad aktami administracji, prowadzonej przez wojewódzkie sądy administracyjne.

Rzetelnym podsumowaniem przerzucania odpowiedzialności za rozpoznanie sprawy za pomocą instytucji decyzji kasatoryjnej jest niewątpliwie pogląd WSA w Gdańsku, którego zdaniem „W sprzeczności z art. $138 \S 2$ k.p.a. pozostaje wydanie decyzji kasacyjnej zarówno w przypadku, gdy zaskarżona decyzja była dotknięta jedynie błędami natury prawnej, jak i w przypadku, gdy postępowanie wyjaśniające organu I instancji jest dotknięte niewielkimi brakami, które z powodzeniem można uzupełnić w postępowaniu odwoławczym na podstawie art. 136 k.p.a. Samo bowiem uzupełnienie dowodów nie jest wystarczającą przesłanką do kasacji decyzji i przekazania sprawy do ponownego rozpoznania"13. To trafne zrozumienie problemu zdecydowanie sprzyja nakreślonemu zarzutowi przewlekłego toku postępowania administracyjnego, czego przyczyną jest w pewnej części niewłaściwe stosowanie decyzji

\footnotetext{
${ }^{12}$ Wskazuje na to liczne orzecznictwo, gdzie wskazuje się przykładowo, że nieprawidłowa ocena materiału dowodowego przez organ I instancji wyklucza możliwość kasacyjnego rozstrzygnięcia w instancji odwoławczej w przypadku, gdy spornym wątkiem sprawy będzie ocenny charakter zebranego materiału w toku postępowania (wyrok WSA w Łodzi z 21.2.2018r., sygn. akt II Sa/Ld 896/17, LEX nr 2446926).

${ }^{13}$ Wyrok WSA w Gdańsku z 24.1.2018r., sygn. akt II SA/Gd 715/17, LEX nr 2441264.
} 
MŁODY JURYSTA 2018/4 - numer specjalny - I Konferencja Młodych Naukowców Prawa Administracyjnego

kasacyjnej. Koniecznym jest wskazanie dotyczące próby przeciwdziałania temu zjawisku. Otóż, organ I instancji od chwili wydania decyzji kasacyjnej będzie związany treścią tej decyzji, a konkretnie zaleceniami dotyczącymi czynności procesowych, którym musi dać zadość ponowne rozpoznanie sprawy, by nowa decyzja nie była ponownie dotknięta adą $^{14}$. $\mathrm{Na}$ tej podstawie dopiero organ I instancji może ustosunkować się w uzasadnieniu decyzji administracyjnej do zaleceń instancji odwoławczej. Należałoby zatem stanąć na stanowisku, że choć KPA nie determinuje w swych przepisach bezpośredniego obowiązku o charakterze dyrektywalnym, to jednak z dyspozycji art. $138 \S 2$ KPA wywieść można pogląd, że organ biorąc pod uwagę zalecenia musi jednocześnie skonfrontować je ze zgromadzonym materiałem dowodowym, przez co de facto wykonuje to zalecenie konkludentnie przez sam fakt konfrontacji. Bez tego przedsięwzięcia nie byłby w stanie obiektywnie stanąć na stanowisku uzasadniając kolejną decyzję - czy i w jakim zakresie zalecenia przyczyniły się do kształtu osnowy nowego aktu.

\section{Wydanie decyzji kasatoryjnej w kontekście uprawnienia strony do czynnego udziału w postępowaniu administracyjnym}

Przechodząc do nakreślenia uprawnień strony związanych z omawianym zagadnieniem koniecznym jest wspomnieć o sytuacji procesowej strony w ogólności. W głównej mierze związana jest z zasadami ogólnymi KPA, z których wywodzi się swoista cecha strony procedury administracyjnej, a mianowicie jej aktywność procesowa. Istotne jest także wskazanie, że strona ma prawo oczekiwać od organu administracji publicznej działania w sposób rzetelny i profesjonalny. Widoczne jest to w przypadku zaskarżania decyzji administracyjnych.

Uprawnieniem strony jest możliwość czynnego udziału w postępowaniu, co gwarantuje art. 10 KPA. Oczywistym jest fakt, że wskazany podmiot może nie skorzystać z przedmiotowego prawa, co jednakże nie ujmuje obowiązkom wynikającym z przepisów szczególnych. Aktywność procesowa strony nie może być niesprecyzowana. Wyznacza ona pewien kierunek poczynań w celu zaspokojenia żądań w sferze prawa administracyjnego.

Czynny udział w postępowaniu administracyjnym jest niezwykle istotny z punktu widzenia aksjologii prawa. Wpływa on niewątpliwie na zwiększanie zaufania obywateli

\footnotetext{
${ }^{14}$ Por. wyrok WSA w Rzeszowie z 20.2.2018r., sygn. akt II Sa/Rz 745/16, LEX nr 2448587.
} 
MŁODY JURYSTA 2018/4 - numer specjalny - I Konferencja Młodych Naukowców Prawa Administracyjnego

do instytucji państwowych, które - zobligowane dyspozycją artykułu 9 KPA - czuwają nad tym, by obywatel jako strona postępowania administracyjnego, przez swoje decyzje procesowe, nie poniósł szkody z tytułu nieznajomości prawa.

\section{Usprawnienie kompetencji strony postępowania administracyjnego przez wprowadzenie instytucji sprzeciwu od decyzji kasatoryjnej}

Ustawą nowelizującą KPA oraz, w szczególności także PPSA ${ }^{15}$, wprowadzono instytucję sprzeciwu od decyzji kasatoryjnej. Określono, że „sprzeciw będzie środkiem zaskarżenia, którym strona będzie mogła zainicjować swoiste postępowanie o charakterze wpadkowym, ograniczone przedmiotowo do kwestii natury formalnej. Podobnie jak zażalenie przewidziane w art. $394^{1} \S 11$ k.p.c. sprzeciw nie będzie środkiem prawnym służącym kontroli materialnoprawnej podstawy decyzji ani prawidłowości zastosowania przez organ drugiej instancji przepisów prawa procesowego niezwiązanych z podstawami kasatoryjnymi. Sprzeciw będzie skierowany przeciwko uchyleniu decyzji i przekazaniu sprawy do ponownego rozpoznania $(\ldots)^{116}$. Będzie to zatem swoisty hamulec w rękach strony postępowania niezadowolonej orzeczeniem decyzji kasacyjnej. Wprowadzona możliwość nie pozwoli na większą podmiotowość strony, gdyż jedynie zastąpi niegdyś obowiązującą skargę na omawiany typ decyzji. Sprzeciw ma jednak przyczynić się do zwiększenia efektywności zaskarżania decyzji, jednocześnie zmniejszając jej skomplikowanie dla strony postępowania. W uzasadnieniu projektu ustawy KPA zawarto stwierdzenie, że „efektywność zaskarżenia decyzji kasatoryjnej i wikłania się przez stronę w długotrwały spór sądowy, co do istnienia podstaw do takiego rozstrzygnięcia jest poważnie ograniczona. Rozwiązanie przewidziane $\mathrm{w}$ art. 64a-64e p.p.s.a. niweluje te niedogodności, wprowadzając szybszy i mniej skomplikowany od procedury skargowej tryb zaskarżania decyzji kasatoryjnych, w którym podobnie jak w przypadku innych przejawów przewlekłości postępowania - możliwe będzie wymierzenie organowi grzywny. Powinno to przyczynić się do zmniejszenia liczby decyzji kasatoryjnych wydawanych przez organ odwoławczy zbyt pochopnie, mimo obiektywnej możliwości załatwienia sprawy merytorycznie i wydania decyzji, o której mowa w art. $138 \S 1$

\footnotetext{
${ }^{15}$ Ustawa z 7.4.2017 r. o zmianie ustawy - Kodeks postępowania administracyjnego oraz niektórych innych ustaw, Dz.U. z 2017 r., poz. 935.

${ }^{16} \mathrm{http}$ ://orka.sejm.gov.pl/Druki8ka.nsf/0/F3388D1AB00B1313C125809D004C3C8E/\%24File/1183.pdf, dostęp z 25.10. 2017r.
} 
MŁODY JURYSTA 2018/4 - numer specjalny - I Konferencja Młodych Naukowców Prawa Administracyjnego

pkt 1 lub 2 k.p.a. Sprzeciw od decyzji kasatoryjnej powinien zatem mobilizować organ odwoławczy do wykonania jego ustawowej funkcji wynikającej z obowiązku dwukrotnego merytorycznego, a nie wyłącznie kontrolnego rozpatrzenia sprawy"17. Niejednokrotnie podnoszona przewlekłość postępowań natury administracyjnej spotkała się ze zrozumieniem ustawodawcy. Należy jednak podkreślić, że pod pojęciem „postępowanie administracyjne” kryje się nie tyle postępowanie przed sądami administracyjnymi, lecz całość postępowań opartych o KPA. Mylne jest bowiem twierdzenie, że sądownictwo administracyjne działa przewlekle ${ }^{18}$.

Sprzeciw od decyzji kasatoryjnej - z mocy PPSA - wnoszony jest w terminie 14 dni do WSA właściwego miejscowo do rozpoznania sprzeciwu. Kontrolny charakter nowej instytucji podkreśla także ustawodawca $\mathrm{w}$ uzasadnieniu projektowanych wówczas zmian: „instytucja ta ma służyć skontrolowaniu, czy decyzja kasatoryjna organu drugiej instancji, która w obowiązującym systemie powinna być wyjątkiem od zasady merytorycznego rozstrzygnięcia sprawy, została wydana prawidłowo i oparta na jednej $z$ podstaw wymienionych w art. $138 \S 2$ k.p.a."19. Podkreślić należy, że sąd administracyjny nie będzie miał kompetencji rozstrzygania sprawy co do jej istoty, jedynie będzie - przy uwzględnieniu sprzeciwu - ‘hamulcem' wobec wizji ponownego rozpatrywania sprawy przez organ I instancji. Świadomość tej cechy jest na tyle istotna, że warunkuje ograniczoną możliwość wnoszenia przedmiotowego środka prawnego. Sąd administracyjny bowiem związany będzie orzekaniem, co do formalnej kontroli nad zapadłą decyzją, zgodnie $\mathrm{z}$ dyspozycją art. 64e PPSA. Wojewódzkie sądy administracyjne mają natomiast kompetencje do ścisłej kontroli zastosowania art. $138 \S 2 \mathrm{KPA}$, a konkretnie stwierdzając istnienie przesłanek bądź jego brak uwzględnia sprzeciw lub go oddala. Nie jest rolą sądu administracyjnego orzekanie co do meritum, gdyż sprzeciw składany jest na decyzję kasatoryjną, dotyczącą ponownego rozpoznania sprawy przez organ I instancji, a nie na rozstrzygnięcia kończącego postępowanie W sprawie.

\footnotetext{
${ }^{17}$ Ibidem.

${ }^{18} \mathrm{http}$ :/prawo.gazetaprawna.pl/artykuly/865963, hauser-jest-dobrze-bedzie-jeszcze-lepiej-szybciej-iskuteczniej.html, dostęp z 25.10.2017r.

${ }^{19} \mathrm{http}: / /$ orka.sejm.gov.pl/Druki8ka.nsf/0/F3388D1AB00B1313C125809D004C3C8E/\%24File/1183.pdf, dostęp z 25.10.2017r.
} 
MŁODY JURYSTA 2018/4 - numer specjalny - I Konferencja Młodych Naukowców Prawa Administracyjnego

\section{Orzecznictwo wobec praktycznego zastosowania instytucji sprzeciwu od decyzji kasatoryjnej w postępowaniu administracyjnym}

Przy ocenie praktycznego zastosowania norm wprowadzonych omawianą reformą nie sposób pominąć poglądów sądownictwa administracyjnego. Przede wszystkim podkreślenia wymaga fakt wspomnianej kategoryzacji sprzeciwu jako instytucji. Warte aprobaty jest stanowisko WSA w Poznaniu, który stwierdził, że: „sprzeciw nie jest środkiem prawnym służącym kontroli materialnoprawnej podstawy decyzji ani prawidłowości zastosowania przez organ drugiej instancji przepisów prawa procesowego niezwiązanych z podstawami kasatoryjnymi. Sprzeciw jest kierowany przeciwko uchyleniu decyzji i przekazaniu sprawy do ponownego rozpoznania. Kontrola dokonywana przez sąd administracyjny $\mathrm{w}$ ramach tego środka ma charakter formalny. Innymi słowy instytucja sprzeciwu służy skontrolowaniu, czy decyzja kasatoryjna organu drugiej instancji została oparta na jednej z podstaw wymienionych w art. $138 \S 2$ k.p.a." 20

Przywołując powyższe orzeczenie warto wspomnieć o aktualności problemu interpretacji przepisów dotyczących sprzeciwu od decyzji kasatoryjnej. Wprowadzone novum poprzez uproszczenie drogi prawnej stronie sporu w postępowaniu administracyjnym nastręczyło pewnych trudności. Orzeczenie zapadło 8.8.2017 r., co wskazuje na to, że kilka miesiący po wejściu w życie zmian w KPA problemy interpretacyjne są podobne, jak przed zmianami. Sądy administracyjne wskazując na specyficzną naturę prawną sprzeciwu od decyzji kasacyjnej, determinują ad hoc ograniczony katalog przyczyn, dla których te decyzje moga zostać uchylone. Po raz kolejny powtórzyć należy, że wojewódzkie sądy administracyjne nie mają w kompetencji badania stanu faktycznego, a jedynie formalne aspekty wydania przedmiotowej decyzji. Na pierwszy rzut oka twierdzenie nie powodujące wątpliwości, traktowane jest jednak za przyczynek do wnoszenia quasi apelacji do sądu, co jest niewątpliwie próbą obejścia obowiązujących przepisów i doprowadzenia do zmiany treści decyzji, a nie do jej uchylenia. Decyzja kasatoryjna jest stanowiskiem organu administracji, która - nie decydując o stanie faktycznym (ustalonym w postępowaniu dowodowym przed organem I instancji) - nakazuje ponowne rozpoznanie sprawy organowi I instancji. Co więcej, za NSA wskazać należy, że „w przypadku wad postępowania wyjaśniającego nie ma prawnej możliwości orzekania na podstawie art. $138 \S 1$ pkt 2 k.p.a." ${ }^{21}$. Mylne rozumienie tego

\footnotetext{
${ }^{20}$ Wyrok WSA w Poznaniu z 8.8.2017 r., sygn. akt IV SA/Po 649/17, LEX nr 2341954.

${ }^{21}$ Wyrok NSA w Warszawie z 20.2.2014 r., sygn. akt II GSK 1952/12, LEX nr 1450732.
} 
MŁODY JURYSTA 2018/4 - numer specjalny - I Konferencja Młodych Naukowców Prawa Administracyjnego

podstawowego znaczenia skutkuje błędnym formułowaniem sprzeciwów, a - w efekcie - ich odrzuceniem.

\section{Wnioski de lege lata uksztaltowane na gruncie analizy uprawnienia strony postępowania administracyjnego do wniesienia sprzeciwu od decyzji kasatoryjnej}

Decyzja kasatoryjna ma charakter ekstraordynaryjny. Zastosowanie tej instytucji powinno iść za przesłankami art. $138 \S 2 \mathrm{KPA}$; nie może bowiem organ odwoławczy stosować decyzji kasacyjnej w celu przerzucenia prowadzenia postępowania administracyjnego na organ, który wydał decyzję w I instancji. Słuszne zatem jest stanowisko, że „decyzja kasatoryjna stanowi wyjątek i nie może stanowić sposobu na uchylenie się organu II instancji od merytorycznego rozpoznania sprawy w sytuacji, w której nie istnieje taka okoliczność natury dowodowej, która uzasadnia przeprowadzenie postępowania dowodowego w znacznej części lub w całości" 22 . Nie można także stosować jej w przypadkach wykraczających poza dyspozycję normy omawianego przepisu KPA. Katalog określonych w nim przesłanek ma charakter zamknięty. Dotyczą one istotnego wpływu na rozstrzygnięcie, które miałoby wyjaśnić we wznowionym postępowaniu administracyjnym kluczowe dla danej sprawy kwestie. Co więcej, decyzja kasatoryjna nie służy do przywracania postępowaniu pierwszoinstancyjnemu charakteru naprawczego w stosunku do niewielkich wad, którym $\mathrm{z}$ łatwością można by sprostać $\mathrm{w}$ postępowaniu odwoławczym w trybie art. $136 \mathrm{KPA}^{23}$. I tak, na przykład „decyzja kasacyjna nie może zostać wydana, jeśli kwestią sporną będzie tylko ocena prawna zebranego materiału dowodowego w sprawie"24.

Zmiany mające na celu ułatwienie i usprawnienie wniesienia sprzeciwu od decyzji kasatoryjnej oceniać należy pozytywnie. Postępowanie prowadzone w trybie uproszczonym, ze stosunkowo krótkim terminem na rozpoznanie, daje gwarancję zajęcia się sprawą bez zbędnej zwłoki. Zastąpienie od 1.6.2017 r. skargi sprzeciwem nakłada na stronę jedynie żądanie uchylenia decyzji kasatoryjnej ze wskazaniem samej decyzji oraz organu, który ją wydał. Nie ma już miejsca na żmudne postępowanie związane z zaskarżeniem decyzji kasatoryjnej do sądu administracyjnego. Nie ma także postępowania dowodowego, a rozpoznanie

\footnotetext{
${ }^{22}$ Wyrok WSA w Krakowie z 19.7.2017 r., sygn. akt III SA/Kr 552/17, LEX nr 2339519.

${ }^{23} \mathrm{Na}$ podobnym stanowisku stanął WSA w Gdańsku w orzeczeniu z 14.10.2015 r., sygn. akt II Sa/Gd 140/15, LEX nr 1948784, a także WSA w Warszawie w orzeczeniu z 26.2.2016 r., sygn. akt II OSK 1619/14, LEX nr 2037417.

${ }^{24}$ Wyrok WSA w Krakowie z 24.8.2017 r., sygn. akt III SA/Kr 834/17, LEX nr 2347516.
} 
MŁODY JURYSTA 2018/4 - numer specjalny - I Konferencja Młodych Naukowców Prawa Administracyjnego

sprzeciwu, co do zasady, odbywa się na posiedzeniu niejawnym, co przyspiesza wydanie orzeczenia. Nie jest wymagana rozprawa, a co za tym idzie, procedura wezwania stron oraz przeprowadzenie ewentualnych dowodów. Strona postępowania ma także możliwość wniesienia skargi kasacyjnej do NSA, czego pozbawiony został organ. Może on wnieść zażalenie co do ewentualnej grzywny nałożonej nań przez sąd. Zmiany wydają się zatem być spójne i kierunkować postępowanie administracyjne tak, by droga odwoławcza od decyzji kasatoryjnej nie była dłuższa niż sam rdzeń toczonego postępowania w konkretnej sprawie.

Całość elementów składających się na instytucję decyzji kasacyjnej jest koherentna i klarowna. Stosunkowo bogate orzecznictwo w tym zakresie pozwala rozwiać wszelkie wątpliwości dotyczące zastosowania sprzeciwu od decyzji kasatoryjnej. Utrzymany został także pogląd wypracowany w praktyce orzeczniczej sądów administracyjnych, a dotyczący natury decyzji kasatoryjnej jako takiej. Z poglądem tym należy się oczywiście zgodzić, gdyż w świetle obowiązujących przepisów, charakter prawny tej instytucji nie ulega zmianie.

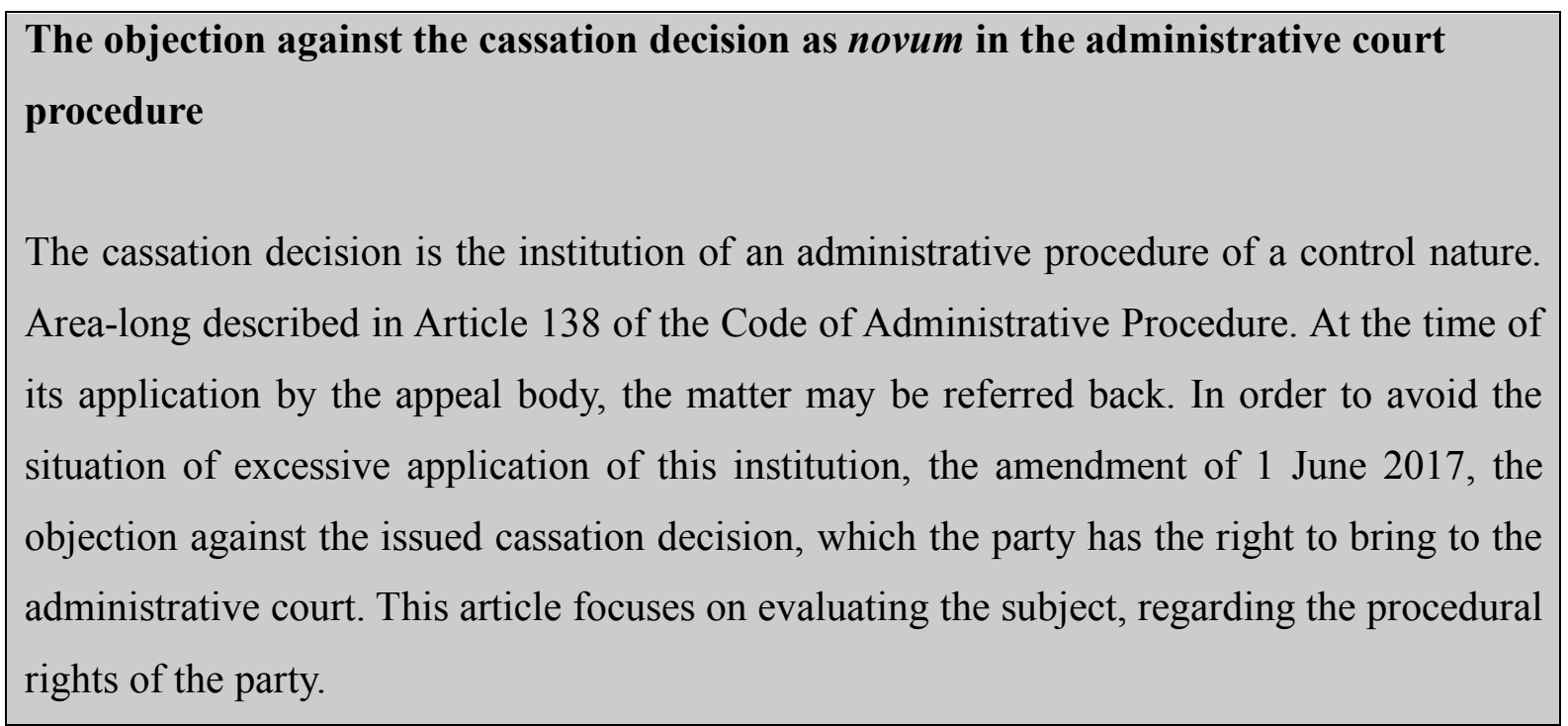

\section{Sebastian Czechowicz}

Student kierunku prawo na Wydziale Prawa i Administracji Uniwersytetu Rzeszowskiego 